\title{
Creation and destruction of comparative advantage by public investment in the transport infrastructure of transit economies and by environmental taxes
}

Citation for published version (APA):

Ziesemer, T. H. W. (1998). Creation and destruction of comparative advantage by public investment in the transport infrastructure of transit economies and by environmental taxes. MERIT, Maastricht Economic Research Institute on Innovation and Technology. MERIT Research Memoranda No. 019 https://doi.org/10.26481/umamer.1998019

Document status and date:

Published: 01/01/1998

DOI:

10.26481/umamer.1998019

Document Version:

Publisher's PDF, also known as Version of record

Please check the document version of this publication:

- A submitted manuscript is the version of the article upon submission and before peer-review. There can be important differences between the submitted version and the official published version of record.

People interested in the research are advised to contact the author for the final version of the publication, or visit the DOI to the publisher's website.

- The final author version and the galley proof are versions of the publication after peer review.

- The final published version features the final layout of the paper including the volume, issue and page numbers.

Link to publication

\footnotetext{
General rights rights.

- You may freely distribute the URL identifying the publication in the public portal. please follow below link for the End User Agreement:

www.umlib.nl/taverne-license

Take down policy

If you believe that this document breaches copyright please contact us at:

repository@maastrichtuniversity.nl

providing details and we will investigate your claim.
}

Copyright and moral rights for the publications made accessible in the public portal are retained by the authors and/or other copyright owners and it is a condition of accessing publications that users recognise and abide by the legal requirements associated with these

- Users may download and print one copy of any publication from the public portal for the purpose of private study or research.

- You may not further distribute the material or use it for any profit-making activity or commercial gain

If the publication is distributed under the terms of Article 25fa of the Dutch Copyright Act, indicated by the "Taverne" license above, 


\section{CREATION AND DESTRUCTION OF COMPARATIVE ADVANTAGE BY PUBLIC INVESTMENT IN THE TRANSPORT INFRASTRUCTURE OF TRANSIT ECONOMIES AND BY ENVIRONMENTAL TAXES}

Thomas Ziesemer, Maastricht University, MERIT and Department of Economics, PO Box 616, 6200 MD Maastricht, The Netherlands. Tel.: 31-43-3883872, Fax: 31-43-3216518, E-mail: T.Ziesemer@Algec.unimaas.NL .

Abstract: In this paper we show conditions under which the accumulation of public infrastructure capital over time may create the comparative advantage of the production of transport services and destroy that of the production of goods in a market equilibrium of a transit economy. We also show conditions under which it will not change comparative advantage. Moreover, we also show the conditions under which an environmental tax on pollution from transport will shift the specialization back to the production of goods. In the model used, specialization is determined by: the productivity of the sectors; the transit volume; the taxes raised for the use of roads; the world market prices of goods and transport services; and environmental taxes. Gains from trade are analysed and comparative-static properties of globalization and tax policy are discussed.

This paper has been presented at the NAKE day, the KNIE day and in an internal seminar. I am grateful for the comments received. Responsibility is entirely mine. 


\section{CREATION AND DESTRUCTION OF COMPARATIVE ADVANTAGE BY PUBLIC INVESTMENT IN THE TRANSPORT INFRASTRUCTURE OF TRANSIT ECONOMIES AND BY ENVIRONMENTAL TAXES}

\section{Introduction}

It widely accepted that there is a central role for governments in the provision of public investment in infrastructure (see World Bank 1990, 1991). However, what seems to be rather obvious from a macroeconomic point of view (see Haslinger and Ziesemer 1996, Glomm and Ravikumar 1997 and Pfähler, Hofmann and Bönte (1996) for surveys) ${ }^{1}$, may be a bit more problematic once public factors benefit some sectors more than others or are even sector specific. In this case public investment may have an impact on the specialization of sectors and may even change the trade pattern of a country (see McMillan 1978) ${ }^{2}$. However, McMillan does not provide a detailed discussion of the conditions under which the trade pattern does or does not change in his dynamic Ricardian trade model.

In this paper we provide a detailed discussion of a transit economy that has some Ricardian flavour, and at the same time include features other than those discussed in the model of McMillan (1978). ${ }^{3}$ A 'transit economy' is defined as an economy with a strong transport sector that is carrying out the transit of goods from, e.g., an import harbour such as Rotterdam to the 'hinterland', say Germany. Alternatively, one could think of natural resources that have to be transported somewhere from the inside of, e.g., Latin America to the international harbours of some Latin-American country. The public capital that is more or less sector specific in the case of the Netherlands is embodied in public roads, railways and airports. In the case of Latin America one could think of the Hidrovia, a system of rivers going through several Latin American countries to the coastal harbours. A major problem with this type of transport infrastructure investment is that it is directly (maybe in the case of Hidrovia)

${ }^{1}$ Note the difference in emphasis in these surveys. Haslinger and Ziesemer emphasize developing country experience. Glomm and Ravikumar emphasize time-series investigations. Pfähler et al. implicitly emphasize panel-data investigations and therefore are a bit more sceptical on the relevance of extra investment.

${ }^{2}$ Other literature on international trade with public inputs consists of contributions to static trade theory.

${ }^{3}$ McMillan (1978) considers the central planners optimum of an enhanced Ricardian textbook trade model. The level of the stock of a public factor determines the productivity of the two sectors. The investment in the stock of public factors is produced using labour and the stock itself. We consider the market equilibrium of a transit economy with one good in the utility function. The second good is international transport services which pollute the natural environment. The stock of public factors in our model enhances only the productivity of the transport sector. 
or indirectly (via the polluting transport sector) responsible for environmental pollution.

Moreover, the relevance of the transit property of economies is illustrated in the following " cheesy " example. A consumer can buy Italian cheese in the Netherlands and in Denmark and can also buy Dutch and Danish cheese in Italy. The intra-industry trade in cheese between Italy on the one side and Denmark and the Netherlands on the other requires the transport of cheese through Germany and either Austria or Switzerland. Therefore, to some extent Germany, Austria and Switzerland are also transit economies, although the importance for Germany as a transit economy is much less than for the smaller countries such as Austria and Switzerland. When French truck drivers were on strike and blockaded French highways it became evident that Belgian automobile producers strongly depend on Spanish intermediate goods. Thus to a certain degree France is also a transit economy. ${ }^{4}$ The transit function of the countries mentioned makes transportinfrastructure capital very important for international trade.

In sum, the three major problems discussed in this paper are

(i) the conditions for the switch in specialization; (ii) the effects of environmental policy in a transit economy and (iii) the conditions required for the efficiency of public investment and positive gains from trade in the dynamic setting of the model. ${ }^{5}$

McMillan's paper is the only contribution thus far on dynamic theory of international trade and public inputs. This paper adds to the environmental policy dimension. It is the first, within international trade theory, to make international transport costs dependent on public investment ${ }^{6}$. It adds to the small body of literature that allows explicit intertemporal changes in specialization to be studied. Earlier contributions were made by

\section{${ }^{4}$ I am grateful to Luc soete for drawing my attention to these examples.}

${ }^{5} \mathrm{~A}$ summary can be found in the abstract and in section 9 .

${ }^{6}$ International transport costs have been modeled in various ways. Samuelson (1954) models them as a constant percentage of wastage, called ice-berg costs in a so-called evaporation model. Falvey (1976) makes them dependent on the cost of labour and capital in the Heckscher-Ohlin manner with internationally identical transport technologies. Casas (1983) has suggested a production function employing capital and labour 'from the country of origin as well as from the country of destination' 'with technology and market conditions determining each country's contribution' 'in a way that the Falvey model itself can be viewed as a special case'. Mainwaring (1986) makes them dependent on country-specific fixed labour coefficients and wages in the Ricardian manner. In Casas and Choi (1989) they depend on the costs of capital and labour, the factors used to make them, and on economies or dis-economies which are external to the firm but internal to the industry, which are captured by the output of the transport sector used for the domestic and international transport of all goods. In Alam (1991) unit-costs are dependent on the trade volume of a partial equilibrium model. 
McMillan (1987) and Brezis, Krugman and Tsiddon (1993).

In the following section the model is presented. In section 3 the special, stationary case of the model is analysed showing the impact of the stock of public capital on specialization. In section 4 the dynamics of the model are analysed as far as it is independent of special parameter values. In section 5 the special cases of the model are considered. This allows us to see under which parameter values there will be a switch in specialization from output production to that of transport services and under which there will be none. In section 6 some cases are considered under which an increase of environmental taxes may shift the specialization back to the production of goods. In section 7 welfare under autarky and the gains from trade are considered. Section 8 presents some comparative-static effects concerning globalization and taxes. Section 9 summarizes and discusses some topics for future research.

\section{The Model}

Technologies

It is assumed that national trade has no transport costs but international trade does. The production function of the domestic sector for international transport is

$$
\frac{D+C-Y}{K} d(S) x=L_{T}
$$

where D is the transit volume, C aggregate consumption, Y output production, $\mathrm{C}-\mathrm{Y}$ is import of goods, $\mathrm{K}$ the exogenous capacity of a truck, all in units of goods, $t \equiv(D+C-Y) / K$ the number of transports, $d(S)$ the duration of each transport dependent on the stock of infrastructure capital, $S, x$ the share of domestic firms in the international transport of the country and 1-x the share of foreign firms in a country's international transport. The lefthand side of equation (1) denotes hours of transport services delivered and the right hand side denotes the necessary labour input, $L_{T}$. As both sides are measured in hours, equation (1) is a one-to-one technology.

The duration function for a transit, $d(S)$, as drawn in Figure 1 , is assumed to have properties $d^{\prime}<0, d^{\prime}{ }^{\prime}>0, \lim _{\mathrm{S} \rightarrow 0} \mathrm{~d}(\mathrm{~S})=\infty$, $d(\infty)>0$. The assumption that the duration $d(S)$ goes to infinity if infrastructure $S$ goes to zero ensures that the small country modelled has no comparative advantage in transport if there is no infrastructure. 
The reason for this specification is twofold. Driving at higher speed does not only require a truck of better quality but also requires higher quality roads such that it is possible to drive faster if other cars are absent. In addition, a larger volume of road capital may reduce congestion. Newbery (1988, p.167) reports from empirical research that the possible speed decreases with the number of cars but less strongly so the wider the lane is. The production function for output of goods is:

$$
Y=H L_{Y}
$$

where $\mathrm{H}$ is the exogenous level of productivity and $L_{Y}$ the labour input in goods production.

The production function for net-investment in infrastructure capital is assumed to be:

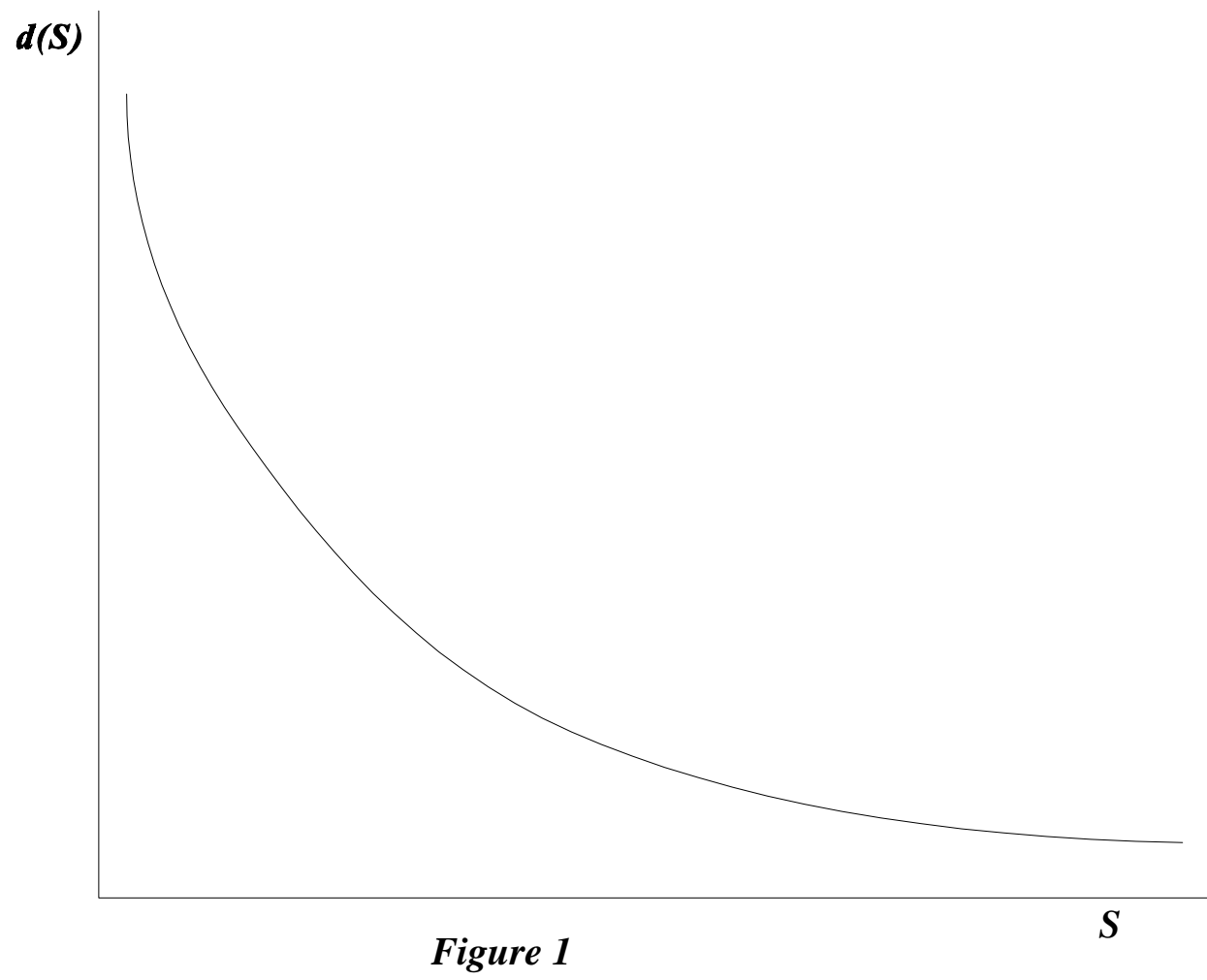

The decrease of transport time if infrastructure is enhanced underlies decreasing returns to scale.

$$
\dot{S}=a L_{S}-\delta_{S} S
$$

where a 'dot' denotes the time-derivative of a variable; 'a' is a labour productivity parameter for gross investment in infrastructure capital, and $\delta_{S}$ is the rate of depreciation of infrastructure capital which is assumed to be constant and given. 
Making the production function dependent on the usage of roads as discussed in Newbery (1988) would not change the qualitative nature of our results. ${ }^{7}$

Resource- and budget constraints

We define:

$$
L_{P}=L_{T}+L_{Y}
$$

where $\mathrm{L}_{\mathrm{p}}$ is the labour available for production which can be used in the production of transport services or goods. The labour market equilibrium condition is:

$$
L_{S}+L_{P}-L=0
$$

Given the absence of fixed costs implicit in the assumptions of the production functions above, we may assume free entry and perfect competition. In the goods sector this assumption is made to simplify the model whereas for road transport it is in accordance with the evidence (see Quinet, 1993).

The non-positive-profit condition for the output producing firm that was characterized by (2) is:

$$
p Y-W L_{Y}=p H L_{Y}-W L_{Y} \leq 0 \text { or } W / p \geq H
$$

If the country produces the output $Y$ the real wage rate is determined by the labour productivity, $H$. If the real wage is higher the country will perfectly specialize in the sense of not producing good $Y$.

The non-positive-profit condition for the transport sector is:

$$
\begin{gathered}
\left(p-\underline{p}-t_{S}-t_{e}\right) \times(D+C-Y)-W L_{T} \leq 0 \\
\left(p-\underline{p}-t_{S}-t_{e}\right) K / d(S)-W \leq 0
\end{gathered}
$$

where $\mathrm{p}$ is the goods price before the transit, ( $\mathrm{p}-\mathrm{p}$ ) is the gross amount of money a transporter earns per unit of goods transported, $t_{s}$ is a road tax paid for each unit of a good that is transported, and $t_{e}$ is a tax for pollution per unit of a good transported. ${ }^{8}$ If the wage is higher than the value of exogenous variables and the level of infrastructure allowed for, then the

${ }^{7}$ As such, for the remainder of the paper, this issue will only be mentioned in footnotes.

${ }^{8}$ This tax structure is chosen because it simplifies the analysis. Paying both tax rates per unit of hour using roads makes the model much more complicated in the stability analysis of the central differential equation (3) and its variants used in the paper. 
firm will make losses and exit, which will imply specialization in the production of goods. This will be shown in the next section. The second formulation has been found by inserting equation (1) for $\mathrm{x}(\mathrm{D}+\mathrm{C}-\mathrm{Y})$ into the first formulation and cancelling out the labour term.

Households are assumed to have materialistic-green preferences defined as $U(C)-V[(D+C-Y)]$, which means that they have utility from consumption per capita, $C=C / L$, and disutility from pollution which is positively related to the number of goods transported. ${ }^{2}$ Transport firms pay environmental taxes in their home country by assumption. The environmental taxes are rebated to households, who spend them together with wage income on consumption goods. Their budget constraint is:

$$
t_{e^{X}}(D+C-Y)+W L=p C L
$$

Road taxes paid by foreign and domestic firms are assumed to be used to pay wages of workers building the roads, which yields the governments budget after cancellation of environmental tax revenues and their rebatement to households:

$$
W L_{S}=t_{S}(D+C-Y)
$$

This mechanism shifts the investment costs to the users. Given the limited information governments can have, it may be more adequate than a dynamically optimal tax scheme based on perfect information analysis. The government is assumed to have determined the road tax by some evaluation that is exogenous to this model.

Finally, we have the trade balance. If transit is undertaken by domestic firms with market share $x$, transit is an export term, $x(p-p) D$. Transport is done by foreigners with market share $1-x$ and therefore the revenues from road taxes, $(1-x) t_{S}(D+C-Y)$, can be viewed as an export of road services. Goods are imported and paid by export revenues from transport or road services. If the transport is by domestic firms, imported goods have to be valued at foreign prices (e.g., as in Rotterdam) xp(C-Y). Finally, if the goods are transported by foreign firms, the transport services are also imported, leading to a valuation at domestic prices, (1$\mathrm{x}) \mathrm{p}(\mathrm{C}-\mathrm{Y})$. In sum, the trade balance can be written as:

$$
x(p-\underline{p}) D+(1-x) t_{S}(D+C-Y)-[x \underline{p}+(1-x) p](C-Y)=0
$$

The trade balance could also be derived by aggregating the budgets of firms, households and the government. Therefore we have only

${ }^{9}$ Relating pollution to hours of transport would give less pollution at lower $d$ and higher s. However, a car would drive faster and pollute more. The latter effect is not explicit in the model but pollution modelled as increasing with the number of goods takes out the above mentioned imbalance between hours and speed. We include only that part of pollution on which the country has an impact, that is its own 'contribution'. 
9 independent equations for the nine endogenous variables $L_{p}, L_{T}$, $L_{Y}, C(=C L), Y, S, L_{S}, W$, and $x . D, K, H, p, p, L, t_{S}$ and $t_{e}$ are exogenous variables and ' $a$ ' and $\delta_{s}$ are

parameters.

Note that this model is designed in a way that does not allow goods to be exported. The reason is as follows (proof by contradiction): If goods were exported on net, then, to have trade balanced, transport services would have to be imported. However, foreign transporters cannot bring goods to domestic households because goods are exported by assumption. If foreign transporters bring domestic goods to foreigners this is a transaction between foreigners which is not counted as trade.

In short, in this model the country imports goods and exports transport and/or road services. In all likelihood conventional trade results could be derived by dis-aggregation of the goods sector into several sectors. This is not undertaken, however, as it is not the major purpose of this paper. Moreover, we would like to point out that the transit volume $D$ is exogenous and not subject to any strategic action as it could be thought of in a strategic game between main ports like Rotterdam, Hamburg and others.

Nevertheless, we next show that the economy can be perfectly specialized either in the production of goods or in transport services. Even if the country specializes in goods production, it will import additional goods paid by the revenues from renting out the roads, which is the case $x=0$ in equation (10). If their is perfect specialization on transport $(\mathrm{Y}=0)$, there is no guarantee that the domestic labour force is large enough for all the transit; therefore $\mathrm{x}<1$ is still possible or, in other words, if all inhabitants of a country work either in transport or road construction, their may still be foreign trucks on the domestic road who pay taxes for using them. In the special case $x=1$, all transit is done by domestic firms and the revenues are used to import goods.

This model has a rather special structure: it deviates from the orthodox set up of having two goods in the utility function, one of which is exported and the other imported. Instead goods are always imported and transport services can be imported or exported, whereas road services are either exported or not. For the sake of simplicity we do not consider the possibility of importing road services. Imagine that goods are delivered to a foreign 'hinterland' country at the border where a foreign transporter takes them over. This is the assumption made by Herberg (1970). Of course the activities of domestic transporters in foreign countries are cut off in a somewhat arbitrary manner, but not doing so would complicate the analysis considerably because a two-country model would be needed.

A transit economy is open by definition. A closed economy version of the model would therefore have no transit volume, $D=0$.

To better understand the model we look at a stationary special case of the model, the properties of which are all relevant for the dynamic version. 


\section{A stationary version of the model}

We make the model stationary by fixing the level of infrastructure, $S$, at an exogenous value, $S^{*}$. The change of $S$ on the left-hand side of (3) therefore is zero and the amount of labour necessary to keep the level $S^{*}$ constant is found from (3) as $L_{S}{ }^{*}=\delta_{s} S^{*} / a$. This in turn fixes $L_{p}$ in $(5)$. $L_{p}$ then can be allocated between transport and output according to equation (4). This is drawn in the lower-left quadrant of Figure 2. The production function (1) is drawn in the upper-left quadrant. As one hour of labour input yields one hour of services delivered, the function is a 45-degree line. The production function (2) is drawn in the lower-right quadrant. The production functions and the labour-input trade off allows us to derive the production possibility curve, which has a horizontal intercept $\mathrm{HL}_{\mathrm{p}}$ and $\mathrm{a}$ vertical intercept $L_{p}$. The slope is therefore $-1 / \mathrm{H}$.

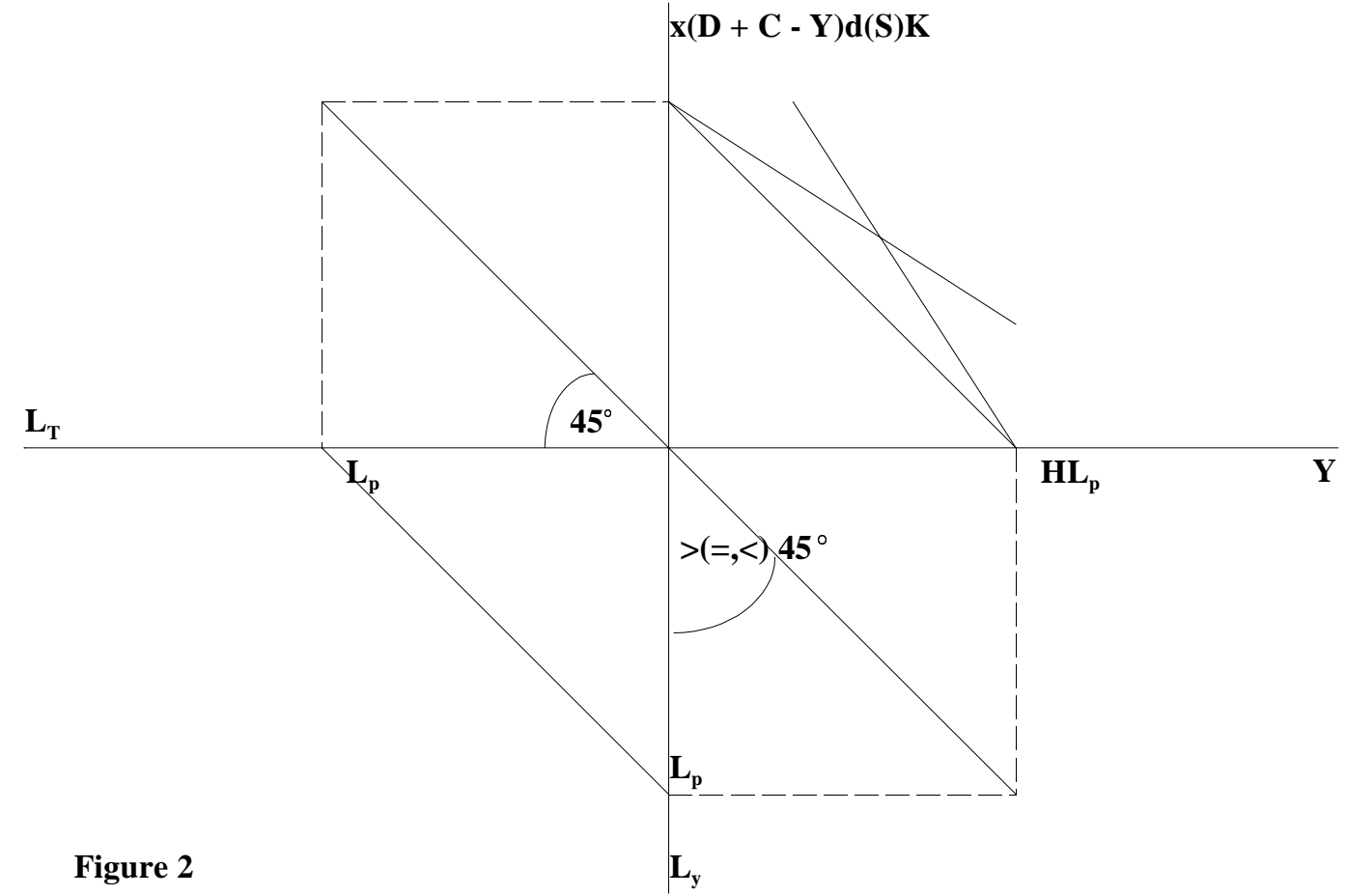

Low (high) taxes and a high (low) level of infrastructure capital lead to specialization in transport services (goods production).

Specialization

The producer price of goods is $p$ and the producer price of transport services (per labour hour and net of taxes) is ( $p-p-$ $\left.t_{s}-t_{e}\right) \mathrm{K} / \mathrm{d}(\mathrm{s})$. It follows from the non-positive profit functions (6) and (7) that the economy will specialize on transport (goods) if $\left(\mathrm{p}-\underline{\mathrm{p}}-\mathrm{t}_{\mathrm{s}}-\mathrm{t}_{\mathrm{e}}\right) \mathrm{K} / \mathrm{d}(\mathrm{S}) \geq(\leq) \mathrm{W} \geq(\leq) \mathrm{pH}$. Dividing the very lefthand side and the very-right hand side by $H$ and the price of transport service hours yields: 


$$
1 / H>(=,<) \frac{p}{\left(p-\underline{p}-t_{S}-t_{e}\right) K / d(S)}
$$

It can be seen from (11) that a relative-price line that is flatter (steeper) than the production-possibility curve leads to a specialization of production on transport (goods). The alternative price lines have been drawn in Figure 2.

The relative price line has some similarity with the termsof-trade line in textbook theory. However, if the economy specializes perfectly in output production, the country will rent out road services and import goods at prices, p, including the costs of the transport services. In this case the terms of trade are $\left[t_{s} K / d(S)\right] / p .{ }^{10}$ Therefore Figure 2 can be used in the usual way to analyse specialization of production but trade has to be analysed somewhat differently (see below).

Specialization is explained now by many variables. Productivity parameters $H$ and $K$ have the same impact as in the simple Ricardian textbook model. However, infrastructure and taxes also have an impact. Higher taxes reduce the net prices of transport and make it less competitive. A higher stock of infrastructure capital, $S^{*}$, reduces the transport duration and therefore increases the competitiveness of the transport sector. For sufficiently low values of infrastructure, $S$, the relative price line would become very steep and therefore the model would generate perfect specialization on production of goods $\left(L_{T}=0\right)$. If taxes and infrastructure go up together, then the effect depends on where the level of infrastructure is in terms of Figure 1. If it is low then the effect of reducing transport costs may be stronger than that of raising taxes. However, if the impact on the duration is low at high levels of $S$, then the effect of taxation may be stronger.

Allowing $S$ and $L_{S}$ to move allows us to analyse changes in the specialization using the upper-right part of Figure 2. If $S$ moves by a change in $L_{s}$ over time then the labour-allocation line would shift inward or outward. This would not effect any of the slopes in this figure except for that of the terms of trade - the slopes will change for one because they are expressed as prices per labour hour whereas they are given from the world market in terms of transport costs per unit of a good and two because infrastructure capital, $S$, changes. To the dynamics of infrastructure capital we turn next.

\section{The Dynamics of the model}

In this section we will analyse the dynamic change in specialization. The level of infrastructure capital, $S$, is assumed to start at a low historical value, say close to zero where transport is not profitable, and will reach a stationary value that is either larger or smaller than that of imperfect

${ }^{10} t_{s}$ is the price of exports per unit of good whereas $t_{s} \mathrm{~K} / \mathrm{d}(\mathrm{S})$ is the price of exports per hour of transport which has been put on the vertical axis of Figure 2 . 
specialization. At imperfect specialization (11) holds with equality. If a stationary value is reached which is lower than the value of imperfect specialization there will be no change in specialization and the economy will always produce goods and no transport services. However, if the stationary value is larger than that of imperfect specialization, specialization will switch to transport once the level of infrastructure capital has grown from a low value to that of imperfect specialization. ${ }^{11}$

The procedure of the analysis is as follows. First, a differential equation for the level of infrastructure is derived. Second, the differential equation is analysed for the special cases of the two perfect specializations of production. In particular, the long-run stationary values of the two specialization regimes are determined. Third, some cases of special assumptions are made (in the next section) which allow to determine the ranking of the size of the long-run values of infrastructure for the two regimes of perfect and imperfect specialization. For these cases it can be clearly concluded whether or not there will be a switch in specialization.

Successive insertion of $L_{s}$ from (9), $C$ from (8) and $Y$ from (2) into (3) yields [with $\mathrm{T}_{e}$ as an abbreviation for the first term of (8); see appendix 1 for a derivation ${ }^{12}$ ]

$$
\dot{S}=a t_{S}\left[D+\left(W L+T_{e}\right) / p-H L_{Y}\right] / W-\delta_{S} S
$$

We distinguish two special cases. First, if there is specialization in the production of goods we have $L_{T}=0, L_{p}=L_{Y}$, $\mathrm{T}_{\mathrm{e}}=0$ and $\mathrm{x}=0$. Second, if there is specialization in transport services we have $L_{Y}=0, L_{p}=L_{T}$ and $x \leq 1$.

In the first case, with specialization in goods, the second equation of (6) holds with equality: $\mathrm{W}=\mathrm{pH}$. Inserting all the relations that define the case into equation (3') we get (see appendix 2 for a derivation):

$$
\dot{S}=a t_{S}\left[D+t_{S} D /\left(p-t_{S}\right)\right] / p H-\delta_{S} S
$$

The stationary value of (3'') for the specialization in goods production can be written as:

${ }^{11}$ It may be helpful to point out that the rest of the world is assumed to be large and has constant steady-state levels of infrastructure and of all other variables. The latter do not change with the specialization of the small country considered. Note that the rest of the world should not be modelled as one that is almost identical to the transit economy considered (as one usually does in trade theory). It is a 'hinterland', parts of which have a transit property which vanishes once these countries are aggregated to be a large 'rest of the world'.

${ }^{12}$ Appendices are available from the author upon request. They can also be downloaded from the Research Memorandum on http://meritbbs.unimaas.nl. 


$$
S^{Y}=a t_{S} D\left[1+\frac{t_{S}}{p-t_{S}}\right] /\left(p H \delta_{S}\right)
$$

which is larger than zero if and only if $\mathrm{p}-t_{\mathrm{S}}>0$ (see appendix 3 for a derivation). For positive net prices of transport services, which we will assume henceforth, this is always fulfilled. It is obvious that the partial derivative of the righthand side of the differential equation with respect to $S$ is negative and therefore the stationary point is stable. ${ }^{13}$

In the second case, C can be solved for from (8) and (10) as a function of $W$ (see appendix 4). Inserting $L_{s}$ from (9) and $W$ from (7) into (3), allows (3) to be written as:

$$
\dot{S}=\frac{a t_{S} d(S)}{\left(p-\underline{p}-t_{S}-t_{e}\right) K}\{D+C[W(S)]\}-\delta_{S} S
$$

with (see appendix 4):

$$
\begin{gathered}
C=\frac{W L\left(p-\underline{p}-t_{S}\right)-t_{e} t_{S} D}{p\left(p-\underline{p}-t_{S}\right)+t_{e}\left(t_{s}-p\right)}= \\
\frac{\left(p-\underline{p}-t_{S}-t_{e}\right) K L\left(p-\underline{p}-t_{S}\right) / d(S)-t_{e} t_{S} D}{p\left(p-\underline{p}-t_{S}-t_{e}\right)+t_{e} t_{S}}
\end{gathered}
$$

with $\mathrm{dC} / \mathrm{dW}>0$, and

$$
W=\left(p-\underline{p}-t_{S}-t_{e}\right) K / d(S)
$$

with $d W / d S>0$ because $d^{\prime}<0$.

The differential equation (3"') has the stationary value:

$$
S^{T}=\frac{a t_{S} d(S)}{K \delta_{S}} \frac{D p+L K\left(p-\underline{p}-t_{S}\right) / d(S)}{p\left(p-\underline{p}-t_{S}-t_{e}\right)+t_{e} t_{S}}
$$

However, at first sight it is anything but clear whether the stationary value is stable. The reason is that the level of infrastructure, $S$, appears three times in (3'''). The effects of the first and the last impact are stabilizing, but the second is not. We first give the formal derivation of (3''') with respect

${ }^{13}$ The stability property would not be changed if the rate of depreciation, $\delta_{s}$, would be dependent on the intensity of the use of roads, $\mathrm{D}+\mathrm{C}-\mathrm{Y}$, because this value is constant in this regime, which can be seen from the derivation of (3''), the first term of which is constant but contained $D+C-Y$ before the manipulations of (3'). 
to $S$ and afterwards the three effects are interpreted. The derivative of (3''') with respect to $S$ is:

$$
\begin{aligned}
\frac{\partial \dot{S}}{\partial S} & =\frac{a t_{S} d^{\prime}(S)}{\left(p-\underline{p}-t_{S}-t_{e}\right) K}\{D+C[W(S)]\} \\
& +\frac{a t_{S} d(S)}{\left(p-\underline{p}-t_{S}-t_{e}\right) K} \frac{\partial C}{\partial W} \frac{\partial W}{\partial S}-\delta_{S}
\end{aligned}
$$

The term in the first line can be interpreted as follows. An increase in infrastructure capital, $S$, increases the productivity of transport firms. This in turn increases the zero-profitequilibrium wage. At a higher wage less workers, $L_{s}$, can be hired for a given amount of tax money. This reduces gross investment in road construction. This effect therefore is stabilizing. However, according to the second effect the wage increase leads to an increase in consumption. As consumption goods are imported under the specialization in transport in this case, the increase in consumption induces an increase in transport. The increase in transport enhances the revenue from road taxes, which is used for hiring more workers for road construction. The consequent increase in gross investment in infrastructure capital reinforces the initial effect and is therefore destabilizing. The third effect is depreciation which, of course, is stabilizing.

After some manipulation it is possible to show (see appendix 5) that equation (3''') can be rewritten as:

$$
\hat{S}=\frac{\left[a t_{S} d(S) / S\right] D / K}{p\left(p-\underline{p}-t_{S}-t_{e}\right)+t_{e} t_{S}}-\delta_{S}+\frac{a t_{S} S^{-1} L\left(p-\underline{p}-t_{S}\right)}{p\left(p-\underline{p}-t_{S}-t_{e}\right)+t_{e} t_{S}}
$$

Higher values of $S$ result in a lower right-hand side of $\left(3^{\text {iv }}\right)$. Therefore this differential equation is stable. ${ }^{14}$ Equations (3'') and $\left(3^{i v}\right)$ have a similar graph the principal form of which is indicated in Figures 3 and 4 .

The crucial question to be treated next is whether the steady stated reached will be $S^{Y}$ or $S^{T}$.

${ }^{14}$ Again the uniqueness and stability property would not be changed if the rate of depreciation would depend positively on usage measured by $\mathrm{D}+\mathrm{C}-\mathrm{Y}$, because $\mathrm{C}$ depends positively on $\mathrm{W}$ which in turn depends positively on $\mathrm{S}$. The negative slope would be there a fortiori. 


\section{Dynamic changes of the trade pattern by growth of infrastructure?}

We define the value of $S$ that will ensure that (11) holds with equality and therefore allows for imperfect specialization as $\mathrm{S}^{\mathrm{I}}$. It follows from (11) and Figure 2 that the economy will specialize in the production of goods if $S<S^{I}$ and in transport if $S^{I}<S$. While $S$ goes from zero to $S^{I}$ there will be specialization on goods production. When $S$ exceeds $S^{I}$ specialization will switch to transport. This means that differential equation (3'') is valid only to the left of $S^{I}$ and differential equation $\left(3^{\text {iv }}\right.$ ) only to the right of $S^{I}$ where they will be drawn as a solid line in the figures below. The crucial question therefore is whether or not

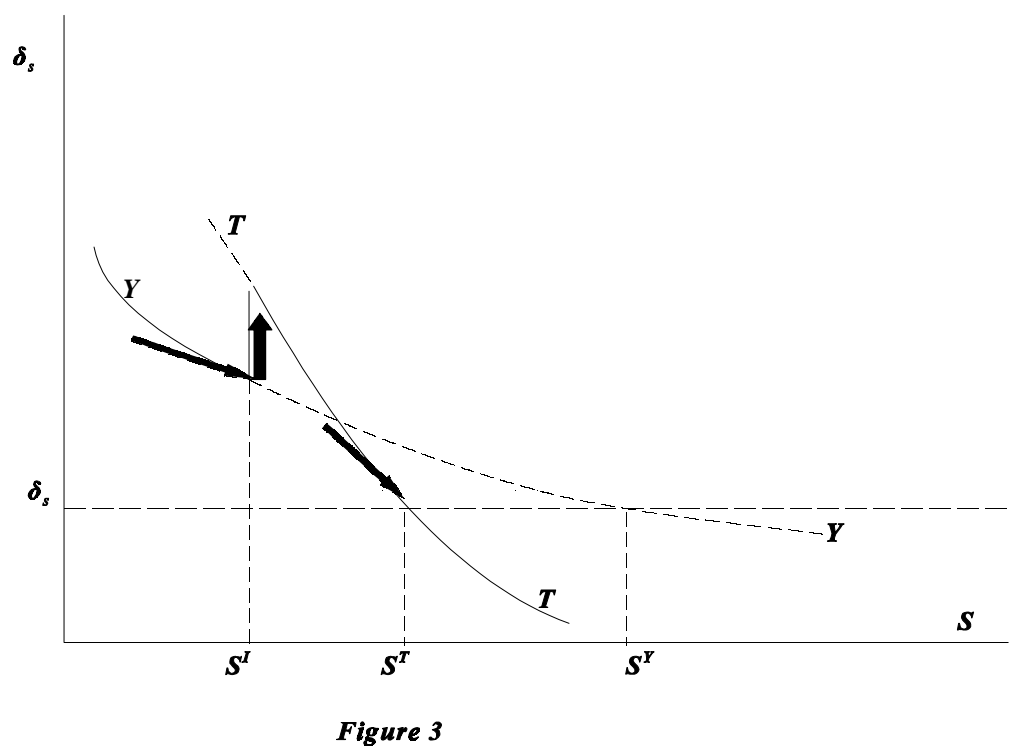

A sufficiently low value of (i) labour productivity in goods production, $H$, (ii) rate of depreciation of transport infrastructure, $\delta_{S}$, and a sufficiently high value of (i) truck productivity, $K$, (ii) labour productivity in public investment, a, (iii) the transit volume, $D$, lead to accumulation of public capital until $S^{I}$, while the economy is specialized on goods production. At $S^{I}$, specialization switches to transport services. Imports, road-tax revenues and investment in public capital jump up and then $S$ moves to $S^{T}$.

$S$ will exceed $S^{I}$. $S$ will not exceed $S^{I}$ if $S^{Y}<S^{I}$, because in this case specialization in goods production will lead to a steady state at $S^{Y}$ before specialization switches. However, $S$ will exceed $S^{I}$ if $S^{I}<S^{Y}$. In the latter case the development of $S$ is described by ( $\left.3^{\prime} '\right)$ as long as $S<S^{I}$ and by $\left(3^{\text {iv }}\right)$ when $S^{I}<S$. When $S^{I}$ is passed there will be a jump

from ( $\left.3^{\prime} '\right)$ to $\left(3^{i v}\right)$. What essentially has to be clarified is the relative position of $S^{Y}$ and $S^{I}$.

It can be readily seen from equations (11) and the solution for $S^{Y}$ that the relative position of $S^{Y}$ and $S^{I}$ depends on the productivity parameters $\mathrm{H}, \mathrm{K}$, ' $^{\mathrm{a}}$ ' and $\delta_{\mathrm{S}}$ for goods, transport and road construction; world economic conditions $\mathrm{D}, \mathrm{p}$ and $\mathrm{p}$; the policy variables $t^{s}$ and $t_{e} ;$ and the size of the economy, $L$. To 
disentangle their respective effects we consider the special cases in which these parameter values are either very high or very low. The discussion of high environmental taxes will be carried out in the next section. It will turn out to be useful to imagine that the effects discussed in this section appear at low or no environmental taxes. In the next section the dynamics considered in this section are combined with environmental taxes.

\section{Low and high productivity in the production of goods}

If $\mathrm{H} \rightarrow \mathrm{O}(\infty)$ then the left-hand side of (11) goes to infinity (zero), which requires that $S^{I}$ goes towards zero (infinity), and $S^{Y}$ goes to infinity (zero). $S^{T}$ is not effected by $H$.

For sufficiently low values of $\mathrm{H}$ we get $S^{\frac{1}{1}}<S^{T}<S^{\mathrm{Y}}$. This case is drawn in Figure 3, where (3'') is denoted as YY (after dividing both sides by $S$ ) and $\left(3^{\text {iv }}\right)$ as TT. To the left of $S^{\text {I }}$ the economy specializes in goods production and creating the comparative advantage of the transport sector it moves along the YY curve until $S^{\mathrm{I}}$ is reached. There it jumps - destroying the comparative advantage of the goods sector - to the TT curve where the transport sector has comparative advantage and moves on $\mathrm{TT}$ until it stops moving at $\mathrm{S}^{\mathrm{T}}$. This jump must be a jump upward of $\mathrm{L}_{\mathrm{S}}$ in (3) for the following reason. Wages are constant at $W=p H$ before the switch. At $S^{\text {I }}$ they are identical for both specializations. After the switch wages move gradually with $\mathrm{S}$ but never jump. According to (8), however, there is a jump in consumption because specialization jumps to transport ( $\mathrm{x}$ jumps from 0 to positive values) and therefore transporters pay environmental taxes and in (9) Y jumps to zero. Therefore there must be an upward jump in $\mathrm{L}^{\mathrm{S}}$ (even if environmental taxes are at zero) .

For sufficiently high values of $H$ we get $S^{Y}<S^{T}<S^{I}$. This case is drawn in Figure 4, where the TT curve is a stippled line until $S^{I}$ because it is valid only to the right of $S^{I}$. The economy moves along the YY curve until $S^{Y}$ and no switch will take place. Transport does not gain a comparative advantage and the goods sector does not loose it.

Low and high productivity in transport services

If $\mathrm{K} \rightarrow 0(\infty)$ (11) requires $\mathrm{S}^{\mathrm{I}} \rightarrow \infty(0), \mathrm{C}$ goes to zero (infinity) in the transport regime and $S^{T}$ goes to infinity (remains finite). $S^{Y}$ is not affected by $K$. For sufficiently low values of $K$ we find $S^{Y}<S^{I}, S^{T}$. Specialization will remain on goods production and the dynamics will be as in Figure 4 although the relative position of $S^{1}$ and $S^{T}$ unclear ${ }^{15}$. For sufficiently high values of $K$ we find $S^{I}<$ $S^{Y}, S^{T}$. Although the relative position of the two steady-state values is unclear, the dynamics will be as in Figure 3 because the curvature of $\mathrm{YY}$ to the right of $\mathrm{S}^{\mathrm{I}}$ is irrelevant.

\footnotetext{
${ }^{15}$ Note that here and in the following, unclear ranking of the steady-state values always occurs in situations when one of them would be in the range of the stippled lines of the graph where the respective differential equation to which they belong does not really exist in the strict mathematical sense.
} 
Low and high productivity in road construction

If 'a' $\rightarrow 0(\infty)$ S $S^{I}$ is not affected, $S^{T} \rightarrow 0(\infty)$ and $S^{Y} \rightarrow 0(\infty)$. For sufficiently low values of ' $a$ ' we get the ranking $S^{T}, S^{Y}<S^{I}$ and therefore no switch occurs. Again the dynamics of Figure 4 are relevant although the relative positions of the steady-state values are unclear. For sufficiently high values of 'a' the

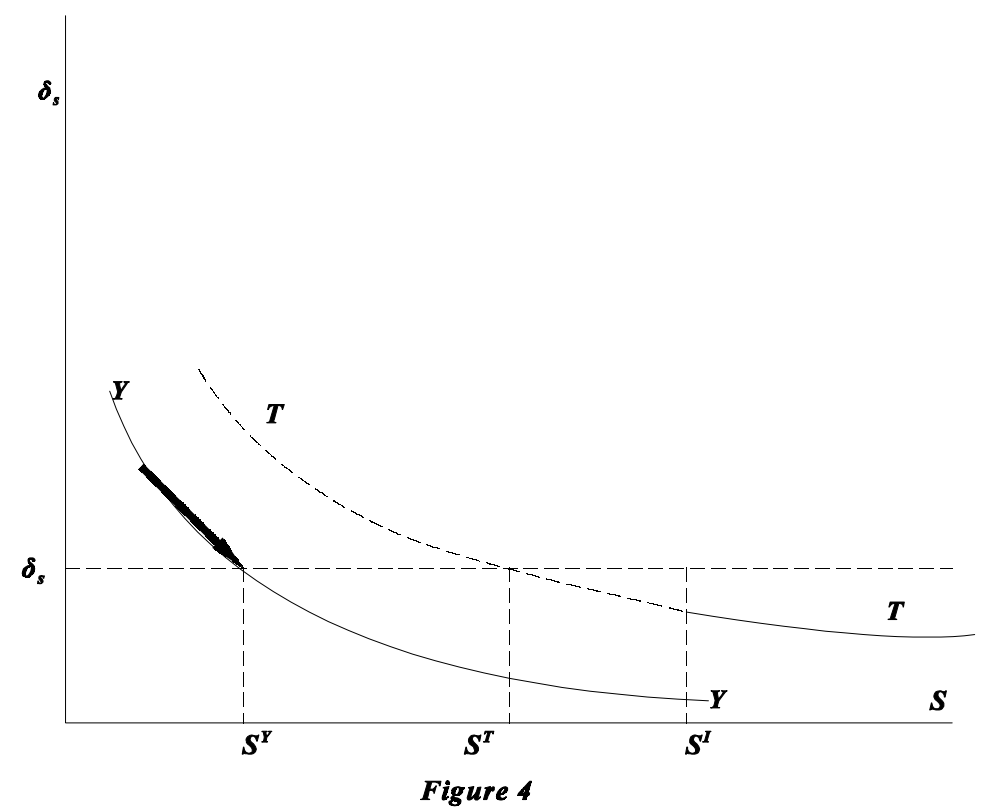

A sufficiently high value of (i) labour productivity in goods production, $H$, (ii) the rate of depreciation of public capital, $\delta_{s}$, (iii) the price of goods, $p$, (iv) the road tax, $t_{s}$, and sufficiently low values of (i) truck productivity, $K$, (ii) labour productivity in public investment, $a$, and (iii) transit volume $D$ lead to public capital accumulation from $S_{0}$ to $S^{Y}$, where the economy remains specialized in goods production.

ranking is $S^{I}<S^{T}$, $S^{Y}$. In this case again the dynamics of Figure 3 are relevant although the relative positions of the steady-state values are unclear again. $\delta_{s} \rightarrow \infty(0)$ has the same effects as 'a' $\rightarrow$ $0(\infty)$. It is left to the reader to check this.

World economic conditions

If $D \rightarrow 0(\infty)$ this has no impact on $S^{I}$ according to (11). $S^{Y}$ goes towards zero (infinity) and $S^{T}$ goes to some finite (infinite) level. For sufficiently low values of $D$ we get the ranking $S^{Y}<S^{I}$, $\mathrm{S}^{\mathrm{T}}$. The process will stop at $\mathrm{S}^{\mathrm{Y}}$ as drawn in Figure 4 although the relative positions of the steady-state values are unclear.

For sufficiently high values of $D$ we get $S^{I}<S^{T}, S^{Y}$. In this case the dynamics of Figure 3 are also relevant although the relative positions of the steady-state values are again.

If $\mathrm{p} \rightarrow \infty, \mathrm{S}^{\mathrm{I}}$ will satisfy $1 / \mathrm{H}=\mathrm{d}(\mathrm{S}) / \mathrm{K}$. $\mathrm{S}^{\mathrm{Y}}$ and $\mathrm{S}^{\mathrm{T}}$ will go towards zero. The process will be as in Figure 5 although the relative position of the steady-state values is unclear. 
If $t_{e}=0$ and net transport prices $\left(p-\underline{p}-t_{s}\right) \rightarrow 0$ because of high $t^{S},(11)$ requires that $S^{I}$ goes to infinity, and $S^{Y}$ and $S^{T}$ will have some finite level. No switch in specialization will take place and the dynamics will again be as in Figure 5.

Country size

The size of L has no clear impact on specialization because L has no impact on $S^{I}$ and $S^{Y}$. However, it has an impact on $S$ Tand therefore an impact on the ranking of the two steady state values. This can be seen from comparing Figures 5 and 6 below.

In sum, if productivity, world economic conditions and taxes are (un-) favourable for the transport sector, there will be specialization on transport (goods) in the long run because the critical value of infrastructure, which determines specialization will be low (high).

\section{Dynamic changes in the trade pattern by environmental policy}

A rise of environmental taxes will be unfavourable for the transport sector in the sense that the net price of transport will decrease. It is clear from equation (11) that such an increase of the environmental tax may shift the specialization from transport services towards goods production. If specialization is in goods production nothing will change, because $t_{e}$ will not affect $S^{Y}$. The only interesting cases are those where the economy is specialized in transport services.

In the following we imagine that there are two phases of 'history': The first phase with low or no environmental taxes is captured by the dynamics as drawn in Figures 3 and 4 . The second phase can be imagined as the dynamics initiated by a rise in environmental taxes if the economy had come to a steady state in the first phase.

Consider the case of low productivity $H$ and high transit volume $D$ as it was captured by Figure 3. A sufficiently strong rise of environmental taxes will shift the TT curve and $S^{\text {I }}$ to the right. In Figure 5 the new values are indicated by an accent. Suppose the starting point were $S^{T}$. As this starting point is to the left of the new imperfect specialization value $S^{I}$, the 


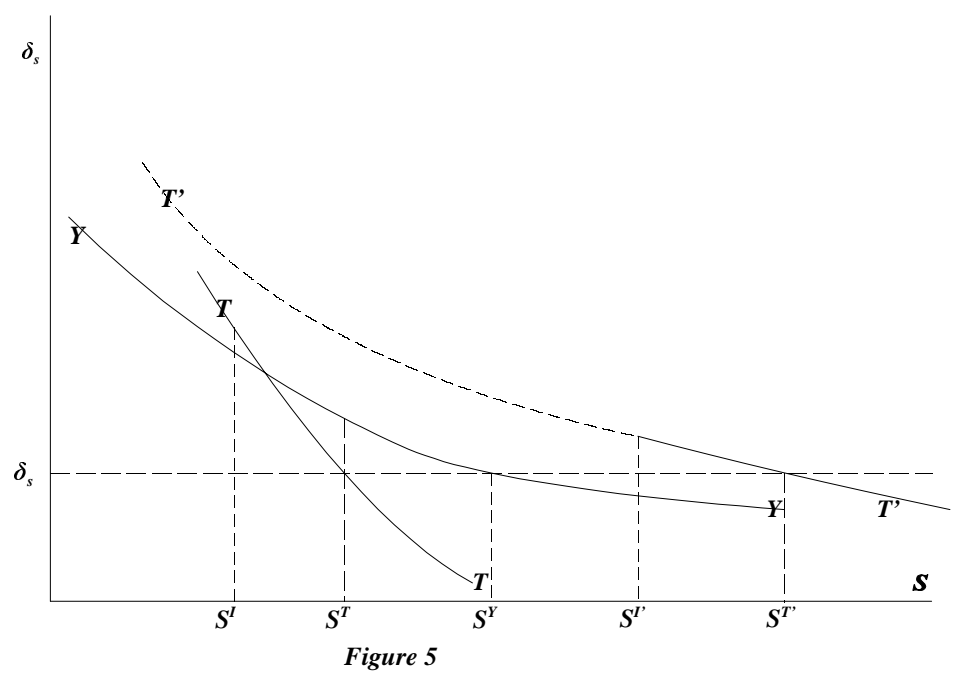

For sufficiently low values of labour productivity in goods production, $H$, and sufficiently high values of the transit volume, $D$, a sufficiently strong increase of environmental taxes shifts $S^{T}$ to high levels such that re-specialization in goods production occurs. Raising environmental taxes decreases wages and imports; investment in road construction becomes cheaper which induces a jump in $d S / S$.

specialization will jump to goods production, i.e. to the line YY. The economy will move to $\mathrm{S}^{\mathrm{Y}}$. Raising environmental taxes induces a switch in specialization implying a drop in wages allowing more workers to be hired. This effect dominates that of consumption reduction from lower wages and the switch in specialization brings $Y$ from zero to some positive value in equation (9) on imports. This follows from the fact that $S^{T}<S^{Y}$ and implies that at $S^{T}$ the YY curve has a higher position than TT. Therefore there must be an upward jump in the beginning of the new process. In other words, low $H$ ensures $S^{I}<S^{T, Y}$ and high $D$ ensures $S^{T}<S^{Y}$ leaving high both transport service hours delivered and road tax revenues.

Next, we consider the case where truck capacity $K$ and labour endowment $\mathrm{L}$ are large enough to yield the ranking ${ }^{16} \mathrm{~S}^{\mathrm{I}}<\mathrm{S}^{\mathrm{Y}}<\mathrm{S}^{\mathrm{T}}$ in the first phase. This case is summarized in Figure 6 . The economy will move on the YY curve until $S^{\text {I }}$ during the first phase. Then it jumps to the TT line because specialization switches and the movement goes to $\mathrm{S}^{\mathrm{T}}$. If an environmental tax shifts the TT line

16 This ranking can be explained as follows. $S^{Y}$ is independent of $K$ and $L$. A sufficiently high value of $K$ can drive $\mathrm{S}^{\mathrm{I}}$ below $\mathrm{S}^{\mathrm{Y}}$. $\mathrm{S}^{\mathrm{I}}$ is independent of $\mathrm{L}$. For any value of $\mathrm{K}$ that ensures $S^{I}<S^{Y}$ a sufficiently high value of $L$ in $\left(3^{\text {iv }}\right.$ ) ensures that $S^{T}$ is larger than $S^{Y}$ which yields this ranking. In a steady state this means that more people work in either transport or goods production and change jobs with a switch in specialization. 
such that $S^{I}$, and $S^{T}$ are in a position to the right of $S^{T}$, then specialization shifts to goods production and the movement on the YY curve goes backward to $S^{Y}$. The decrease in wages according to (7) decreases income and consumption. In this case, the moment the environmental tax is introduced the decrease of imports dominates the change of wages such that imports, road tax revenues and investment in road construction are all going down, because large L leads to high production and very low imports.

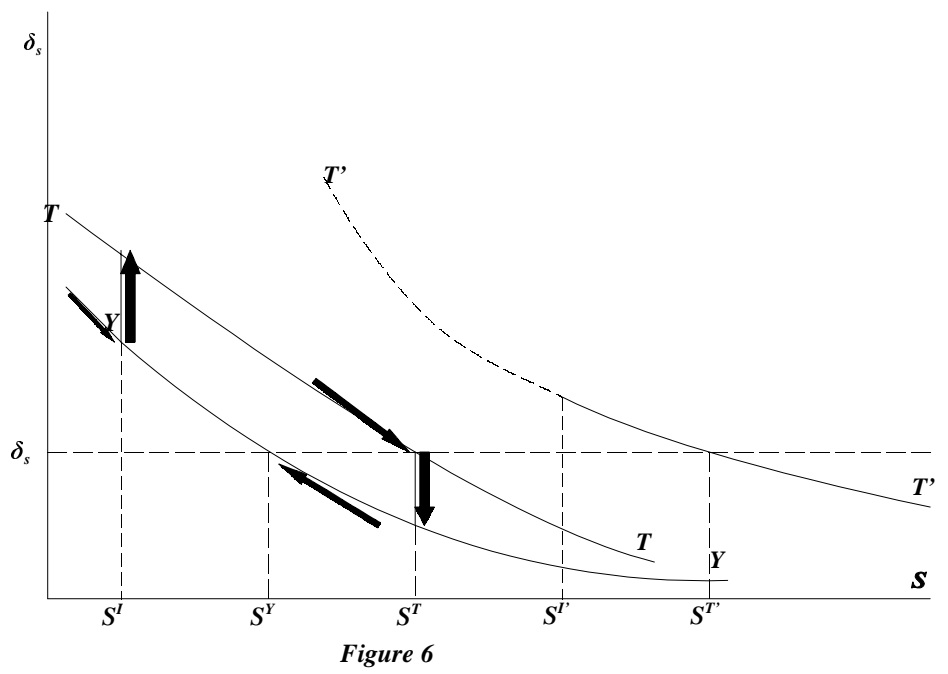

With high truck productivity, $K$, and a large country size $L$, infrastructure capital moves from $S_{0}$ to $S^{I}$, switches specialization and moves on towards $S^{T}$ if there are no or low environmental taxes. A sufficiently strong introduction of environmental taxes induces a negative growth of public capital towards $S^{Y}$.

\section{Autarky and gains from trade}

To be able to study the gains from trade and from public investment we first analyse the autarkic temporary utility level which will be used as a benchmark later.

Under autarky there is no transport by assumption. Therefore reinvestment into infrastructure capital makes no sense and the corresponding labour inputs, $\mathrm{L}_{\mathrm{T}}$ and $\mathrm{L}_{\mathrm{S}}$, will be zero. Consequently, there will be perfect specialization on goods production. Equations (4) and (5) degenerate to $\mathrm{L}=\mathrm{L}_{\mathrm{p}}=\mathrm{L}_{\mathrm{Y}}$. Output must be $\mathrm{Y}$ $=\mathrm{HL}$ and wages are $\mathrm{W}=\mathrm{pH}$. Nominal income can also be written as $\mathrm{WL}=\mathrm{pHL}=\mathrm{pC}=\mathrm{pY}$. Real consumption per capita then is $\mathrm{C}=\mathrm{C} / \mathrm{L}$ $=\mathrm{H}$. The utility level under autarky in the absence of pollution from transport therefore is:

$$
\mathrm{U}(\mathrm{H})-\mathrm{V}(0)
$$

Next we consider the temporary utility levels under free trade for the two phases of specialization. 
If there is specialization on goods production, $\mathrm{x}=0$,

and (6) imply $\mathrm{c}=\mathrm{W} / \mathrm{p}=\mathrm{H}$. (9) implies $\mathrm{D}+\mathrm{C}-\mathrm{Y}=\mathrm{WL}_{\mathrm{S}} / \mathrm{t}_{\mathrm{S}}$. Using the same value of $L_{S}$ as in $\left(3^{\text {ii }}\right)$ we get $D+C-Y=p H D /[(p-$ $\left.\left.t_{s}\right) H\right]$. Temporary utility for specialization in goods production therefore is:

$$
\mathrm{U}(\mathrm{H})-\mathrm{V}\left\{\mathrm{pHD} /\left[\left(\mathrm{p}-\mathrm{t}_{\mathrm{S}}\right) \mathrm{H}\right]\right\}
$$

Temporary utility during the first phase is smaller than that of autarky. The reason is simply that in the special case of this model the production point is unchanged by shifting to free trade except for some workers who are reallocated towards road construction. Specialization under autarky and under free trade is on goods production and therefore real wages and consumption are at the same level in both cases, namely $H$. The export revenues from renting out road services $t_{S} x(D+C-Y)$ are used to import goods the value of which equals the consumption of road workers. In other words, what one might have expected to be the gains from trade is used for paying workers who work on the road construction investment projects, which shifts gains into the future, provided specialization in transport is achieved later where a higher level of infrastructure capital $S$ yields higher wages. Foreign transporters pay environmental taxes at home.

In sum, there is nothing that changes per capita consumption when the economy goes from autarky to free trade. But international transport is allowed for now and it pollutes the natural environment. This decreases the temporary utility as long 


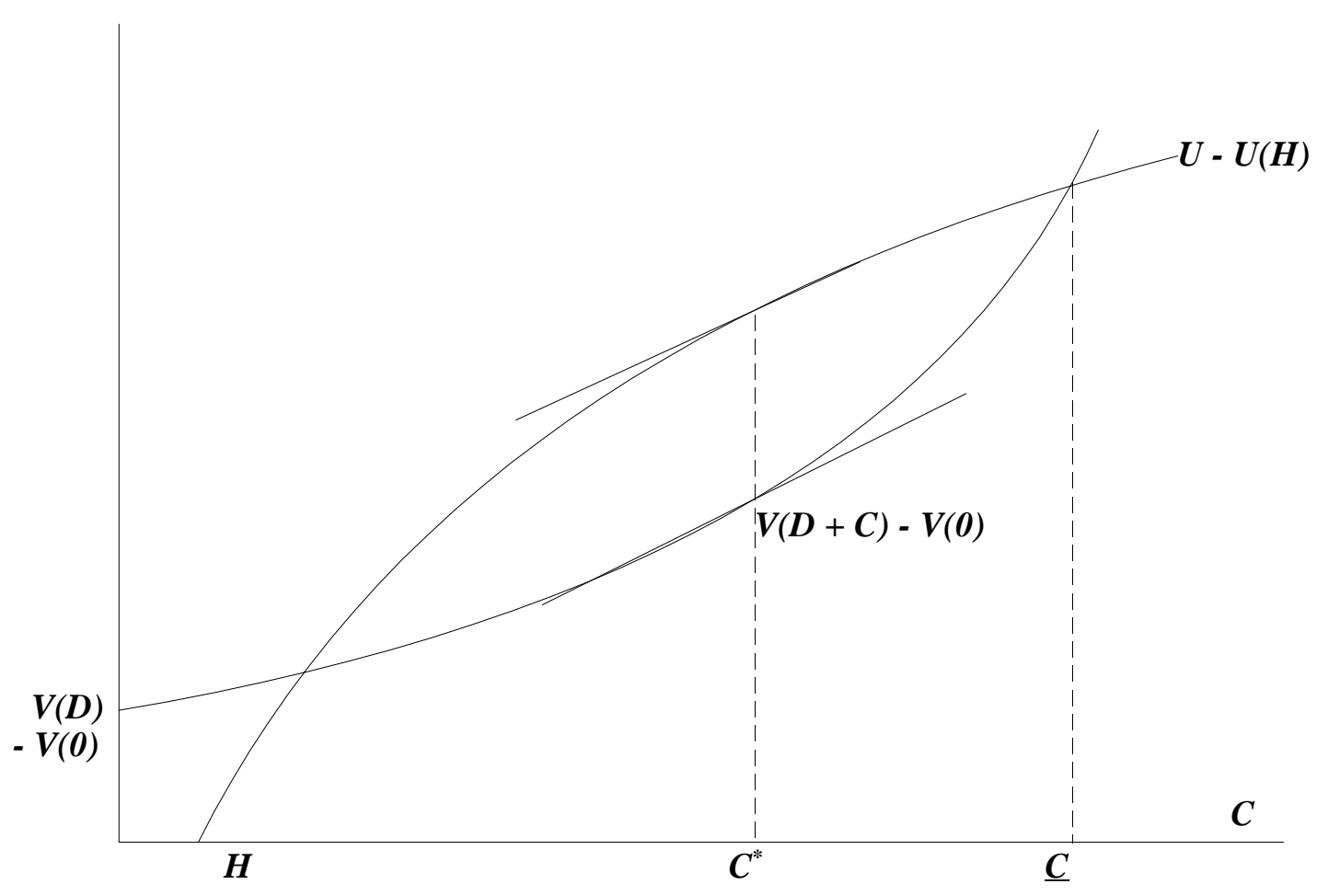

Figure 7

Utility from consumption under specialization on transport must exceed that of autarky by more than that of disutility from pollution.

as specialization is on goods production. During this first phase neither free trade nor public investment are welfare enhancing. Of course, if one dis-aggregates the goods production sector of this model in accordance with assumptions of standard textbook trade models then there will also be gains from trade in this model. The gains from trade in this model therefore should be interpreted as additional gains from transport or road services. The utility level under specialization on transport is

$$
\mathrm{U}[\mathrm{C}(\mathrm{W}) / \mathrm{L}]-\mathrm{V}[\mathrm{D}+\mathrm{C}(\mathrm{W})]
$$

with $\mathrm{C}$ according to (12) and $\mathrm{W}$ according to (13). Consumption per capita is higher under this specialization than under that in the first phase, because (6) now implies that $\mathrm{W}>\mathrm{pH}$ and there may be environmental tax revenues which are rebated to households. It follows then from (8) that per capita consumption in the second phase is higher than with $\mathrm{W}=\mathrm{pH}$ and no environmental tax revenues in the first phase of goods production. Both utility from consumption and disutility from pollution are larger in this second phase than under autarky, because under autarky pollution is zero. A critical necessary condition for free trade to be beneficial therefore is

$$
\mathrm{U}[\mathrm{C}(\mathrm{W}) / \mathrm{L}]-\mathrm{U}(\mathrm{H})>\mathrm{V}[\mathrm{D}+\mathrm{C}(\mathrm{W})]-\mathrm{V}(0)
$$


This means that the higher utility from consumption on the lefthand side must dominate the higher disutility from pollution. This case is drawn in Figure 7 under the additional assumptions $U^{\prime}>0$, $\mathrm{U}^{\prime} '<0, \mathrm{~V}^{\prime}>0, \mathrm{~V}^{\prime}{ }^{\prime}>0$.

Three conditions are required for free trade to be beneficial. First, public investment in infrastructure, $S$, must bring the economy into the trade pattern of specialization on transport. Second, utility functions must be such that there is a range of values of per capita consumption $(H, \underline{c})$ in which $U$ is larger than $V$ and the economy must be in this range when it is specialized on transport services. Third, having welfare losses during the first phase and welfare gains in the second, the somehow discounted gains must outweigh the losses and this difference must be larger than utility under autarky.

Similarly, public investment is beneficial only if there is free trade - because under autarky transport infrastructure is useless under the assumption of no transport costs - and economic conditions that make public investment beneficial must be the same as those that make free trade beneficial.

Free trade and public investment appear simultaneously and therefore their benefits depend on the same necessary conditions: the economy must go on to specialize in transport and must be in a range of consumption values where $U>V$, and discounting of the future should not reverse this. If one of these conditions is not met, then neither free trade nor public investment can be beneficial.

\section{Some comparative-static effects}

Maybe it would be desirable to check what the dynamically optimal policy could be. However, maximizing welfare subject to ( $\left.3^{\prime} '\right)$ and either (3''') or $\left(3^{i v}\right)$ choosing $t_{e}$ and $t_{s}$ is complicated by the fact that ( $3^{\prime \prime}$ ') is strongly convex in $t_{s}$. Moreover, given the fact that we have introduced $t_{s}$ as a short cut device of a government that has imperfect information and therefore decides to tax the use of roads using the tax revenues for investment in road construction, it is not very attractive to now shift to an assumption of perfect information.

However, some interesting comparative-static effects can be identified. We concentrate on the second phase because of its crucial role in generating welfare and because taxes and the transit volume - on which we shall concentrate - have an impact mainly on the transport sector, which the economy specializes on in this phase. We distinguish between the effects on $U-V$ according to (16) in the second phase for a given value of $S$ and the effect on $\mathrm{S}$ in (14) or the shift of $\left(3^{\text {iv }}\right)$ as drawn in Figure 3 respectively.

\section{Globalization}

An increase of $D$ from ongoing globalization has a direct impact on pollution and its disutility. Its effect on $\mathrm{C}$ for $\mathrm{a}$ given $S$ according to (12) is: 


$$
0>\frac{\partial C}{\partial D}=\frac{-t_{e} t_{S}}{p\left(p-\underline{p}-t_{S}-t_{e}\right)+t_{e} t_{S}}>-1
$$

The intuitive reason why consumption is decreasing is that in (10) c.p. there is a decrease of the share in the transport market, $\mathrm{dx}$ $<0$ if $\mathrm{dD}>0$. This reduces environmental revenues in (8), where the indirect effect via $x$ is stronger than the direct effect of $D$ which would increase environmental revenues. Concerning pollution the direct effect of $\mathrm{D}$ is stronger than the indirect effect that $\mathrm{dD}>0$ decreases consumption and therefore imports and pollution. Therefore $\mathrm{dD}>0$ has a negative effect on $U$ and $a$ positive effect on $\mathrm{V}$ implying that $\mathrm{U}-\mathrm{V}$ is decreasing for a given S. For a given $S$ globalization, $\mathrm{dD}>0$, would therefore be damaging. However, an increase of $\mathrm{D}, \mathrm{dD}>0$, would shift the graph of $\left(3^{\text {iv }}\right)$ upward and to the right and therefore would increase the steady-state value of $S$ and of wages in the transport specialization regime. Taking the impact of $\mathrm{D}$ on $\mathrm{S}$ into account, the effects of $\mathrm{D}$ on utility can be written as:

$$
\frac{\partial(U-V)}{\partial D}=\left(U^{\prime}-V^{\prime}\right)\left[\frac{\partial C}{\partial D}+\frac{\partial C}{\partial S} \frac{\partial S}{\partial D}\right]-V^{\prime}
$$

with $\partial C / \partial D<0$ according to (17), $\partial C / \partial S>0$ from (12) and $\partial S / \partial D>$ 0 from (14). Two scenarios will yield a positive effect of $D$ on utility. One must either have preferences which are more materialistic than green, $U^{\prime}-V^{\prime}>0$, and a strong effect of $D$ on $S$ and of $\mathrm{S}$ on $\mathrm{C}$ and a low $\mathrm{V}^{\prime}$ or one must have preferences more green than materialistic, $U^{\prime}-V^{\prime}<0$, and a weak effect of $D$ on $S$ and $S$ on $\mathrm{C}$ and again a low $\mathrm{V}^{\prime} \cdot{ }^{17}$ However, if $t_{e}=0$, we get $\partial \mathrm{C} / \partial \mathrm{D}=0$, and preferences which are more green than materialistic, $U^{\prime}-V^{\prime}$ $<0$, are a sufficient condition for a negative welfare effect of globalization.

\section{Environmental and road taxes}

Taking the derivative of $\mathrm{C}$ in (12) with respect to either road taxes or environmental taxes one can show that an increase of both tax rates reduces consumption for any given level of infrastructure capital, $\mathrm{S}: \partial \mathrm{C} / \partial \mathrm{t}_{\mathrm{e}, \mathrm{s}}<0$. However, it can be seen from (14) that an increase of environmental taxes on the long-run value of $S$ is positive which in turn has a positive impact on consumption. Again the net effect on utility depends on the sign of $U^{\prime}-V^{\prime}$ and on the relative strength of the short and long-run effects.

Besides environmental taxes, road taxes could be an interesting policy instrument to increase public sector capital. As long as environmental taxes are low, it is instructive to look at the case where they are zero. A first direct ceteris paribus

${ }^{17}$ Unfortunately we have been unable so far to construct any special cases which would give some clear-cut results. Without numerical analysis it seems to be impossible at the moment to get any additional insight. 
effect of higher road taxes is to generate more revenues to hire more road workers. Wages are decreased by road taxes for a given level of infrastructure. However, considering (14) with no environmental taxes shows that the net effect on the steady state value of infrastructure capital is positive despite the fact that transporters pay the costs themselves. This in turn increases wages. In the case of no environmental taxes, in the first equation of (12) consumption depends on road taxes only via wages. Consequently with an unclear effect on wages the effect on consumption is also unclear. If transporters would not pay for the use of roads, road taxes had no impact on wages. In this case infrastructure capital would be larger and so would consumption, wages and pollution leading to a similar problem of valuing material gains against environmental losses. However, once transporters pay, all effects are much less clear.

\section{Summary and conclusion}

In this paper we have looked at the effects of public investment, if it is used only by one sector, on the trade pattern, pollution, wages and welfare.

In section 2 we set up a new model of a transit economy with two sectors one of which is the transport sector that depends on infrastructure capital financed by a road tax.

In section 3 we show that the stock of public capital, technology parameters and road and environmental taxes as well as world market prices and the transit volume are the determinants of comparative advantage in the short run.

In section 4 we analysed the dynamics of the accumulation of infrastructure capital that is driven by the mechanism of financing road investment by road taxes.

In section 5 we show that, roughly speaking, the stock of public capital will shift comparative advantage to the transport (goods) sector (under the mechanism of road financing by road taxes) if other conditions concerning productivity, world market and policy are also favourable for the transport (goods) sector.

However, the introduction of an environmental tax, treated in section 6 is a disadvantage for the transport sector and may shift the comparative advantage away from transport services to goods production. The long-run level of public capital in the new regime of goods production may be either higher (see Figure 5) or lower (see Figure 6) than in the regime of specialization on transport before the introduction of environmental policy. This depends on which effect dominates - that of decreasing wages from the tax or that of decreasing revenues from the change in specialization.

The welfare analysis in section 7 shows that welfare under autarky is larger than welfare in the first phase of free trade with specialization in goods because real wages and consumption do not increase but imports and pollution do. In the second phase if there is a switch to specialization in transport services, utility from consumption as well as disutility from pollution are higher than under autarky. If preferences value consumption stronger than pollution in the second phase and do not discount the second phase too strongly, then the overall evaluation of free trade and public investment may be positive only if the losses of 
the first phase are low enough.

Finally, the model shows that the welfare effects of globalization, environmental and road taxes are anything but obvious even when considering the second phase alone. In the short term taxes have negative effects on consumption, but have an opposite effects via the long-run value of infrastructure capital.

Of course, all these results should be taken with caution because of the specific nature of the model. In particular, in future research we will investigate the modification of the results for the case when the government has a second sector specific investment opportunity such as investment in public knowledge which increases productivity of goods production and may foster pollution less than transport infrastructure does. In this case the benefits of infrastructure investments will probably even be lower than in the case of the model discussed above.

\section{References}

Alam,M.S.(1991), A Partial Equilibrium Analysis of Trade with Decreasing Transport Costs, International Economic Journal, Vol.5, No.4, Winter, 63-69.

Brezis, Elise S., Paul R. Krugman and Daniel Tsiddon (1993), leapfrogging in International Competition: A Theory of Cycles in National Technological Leadership, The American Economic Review, December, 1211-1219.

Casas, F.R. (1983), International Trade with Produced Transport Services, Oxford Economic Papers, March, 89-109.

Casas, F.R. and E.K. Choi (1989), Transport Costs and Immiserizing Growth under Variable Returns to Scale, International Journal of Transport Economics, Vol.XVI, No.1, February, 3-18.

Glomm, Gerhard and B. Ravikumar (1997), Productive government expenditures and long-run growth, Journal of Economic Dynamics and Control 21, 183-204.

Haslinger, Franz and Thomas Ziesemer (1996), Endogenous growth and distributional conflict, in: Questioning Development, edited by G.Köhler, C. Gore, U.-P. Reich and T. Ziesemer, Metropolis-Verlag, Marburg 1996, 227-244.

Mainwaring, L. (1986), The Theory of International Transport Costs with Tradable Intermediate Goods, Scottish Journal of Political Economy, Vol.33, No.2, May, 111-123.

McMillan, John (1978), A Dynamic Analysis of Public Intermediate Goods Supply in Open Economy, International Economic Review, Vol.19, No.3, October, 1978, 665-77.

Newbery, David M. (1988), Road User Charges in Britain, The Economic Journal, 98, 161-176.

Quinet, E. (1993), Transport between Monopoly and competition: Supply Side and Markets, European Transport Economics, edited by 
Jacob Polak and Arnold Heertje, Blackwell Publishers, Oxford, UK, and Cambridge, USA.

Pfähler, Wilhelm, Ulrich Hofmann and Werner Bönte (1996), Does Extra Public Infrastructure Capital Matter? An Appraisal of Empirical Literature, Finanzarchiv N.F., Bd.53, 68-112.

Samuelson, Paul A. (1954), The Transfer Problem and Transport costs, II: Analysis of Effects of Trade Impediments, The Economic Journal, June, 264-89.

World Bank (1990, 1991), World Development Report, Oxford: Oxford University Press. 


\section{APPENDICES (NOT FOR PUBLICATION)}

\section{Appendix 1}

Insertion of $\mathrm{L}_{\mathrm{S}}$ from (9) into (3) yields

$$
\dot{S}=a t_{S}(D+C-Y) / W-d_{S} S
$$

Defining $\mathrm{T}_{\mathrm{e}} \equiv \mathrm{t}_{\mathrm{e}} \mathrm{x}(\mathrm{D}+\mathrm{C}-\mathrm{Y})$ in (8) and dividing by $\mathrm{p}$ yields

$$
\left(\mathrm{T}_{\mathrm{e}}+\mathrm{WL}\right) / \mathrm{p}=\mathrm{C}
$$

Insertion of (2) and $\mathrm{C}$ from the right-hand side of the last equation into the previous differential equation yields

$$
\dot{S}=a t_{S}\left[D+\left(W L+T_{e}\right) / p-H L_{Y}\right]-\delta_{S} S
$$

Of course, the first term on the right-hand side equals $a L_{s}$.

\section{Appendix 2}

Insertion of $\mathrm{W}=\mathrm{pH}, \mathrm{T}_{\mathrm{e}}=0$ and $\mathrm{L}_{\mathrm{Y}}=\mathrm{L}_{\mathrm{p}}$ into (3') yields

$$
\dot{S}=a t_{S}\left[D+H\left(L-L_{p}\right)\right] /(p H)-\delta_{S} S
$$

To eliminate $L-L_{p}$ from this equation will deliver a differential equation in $S$ only. As the first term on the right-hand side is $a L_{s}=a\left(L-L_{p}\right)$ we get

$L-L_{p}=t_{S}\left[D+H\left(L-L_{p}\right)\right] /(p H)$

Solving for $\mathrm{L}-\mathrm{L}_{\mathrm{p}}$ yields

$L-L_{p}=t_{S} D /\left[\left(p-t_{S}\right) H\right]$

Insertion of this into the last version of the differential equation yields (3'') in the text:

$$
\dot{S}=a t_{S}\left[D+t_{S} D /\left[p-t_{S}\right] / p H-\delta_{S} S\right.
$$

\section{Appendix 3}

For $S^{Y}>0$ we must have $\left\{1+t_{S} /\left[p-t_{S}\right]\right\} / p H>0$. Multiplying numerator and denominator by $\left[p-t_{s}\right]$ yields $\left[p-t_{s}+t_{s}\right] /\{p H[p-$ $\left.\left.t_{s}\right]\right\}>0$ if $\left[p-t_{s}\right]>0$.

\section{Appendix 4}

With the value of the wage, W, from (7), the zero profit condition 
of the transport firm, the household's budget constraint (8) and the trade balance (10) are two equations for $x$ and C. Solving (8) for $x$ yields

$x=(p C-W L) /\left[t_{e}(D+C)\right]$

Solving (10) for $x$ yields

$x=\left[-t_{S}(D+C)+p C\right] /\left[(p-\underline{p}) D-t_{S}(D+C)-(\underline{p}-p) C\right]$

Equating the right-hand sides of the equations for $x$ yields

$(p C-W L) /\left[t_{e}(D+C)\right]=\left[-t_{S}(D+C)+p C\right] /\left[(p-p) D-t_{S}(D+C)-(\underline{p}-\right.$ p) C]

Solving for C yields:

$$
\begin{gathered}
C=\frac{\frac{W L}{t_{e}}-\frac{t_{S} D}{p-\underline{p}-t_{S}}}{\frac{p}{t_{e}}+\frac{t_{S}-p}{p-\underline{p}-t_{S}}}=\frac{W L\left(p-\underline{p}-t_{S}\right)-t_{e} t_{S} D}{p\left(p-\underline{p}-t_{S}\right)+t_{e}\left(t_{S}-p\right)}= \\
\frac{\left(p-\underline{p}-t_{S}-t_{e}\right) K L\left(p-\underline{p}-t_{S}\right) / d(S)-t_{e} t_{S} D}{p\left(p-\underline{p}-t_{S}\right)+t_{e}\left(t_{S}-p\right)}
\end{gathered}
$$

\section{Appendix 5}

Dividing (3''') by $S$, inserting the results for $C$ and $W$ from appendix 4, and carrying out the multiplication of the first of the two terms in (3'') yields

$$
\begin{gathered}
\hat{S}=\frac{a t_{S} d(S) / S}{K\left(p-\underline{p}-t_{S}-t_{e}\right)} D \\
+\frac{a t_{S} S^{-1} L\left(p-\underline{p}-t_{S}-t_{e}\right) K\left(p-\underline{p}-t_{S}\right)}{\left(p-\underline{p}-t_{S}-t_{e}\right) K\left[p\left(p-\underline{p}-t_{S}-t_{e}\right)+t_{e} t_{S}\right]} \\
-\frac{\left[a t_{S} d(S) / S\right] t_{e} t_{S} D}{\left.\left(p-\underline{p}-t_{S}-t_{e}\right) K\left[p\left(p-\underline{p}-t_{S}-t_{e}\right)-t_{e} t_{S}\right)\right]}-\delta_{S}
\end{gathered}
$$

Collecting $d(S)$-terms and cancelling ( $\left.p-\underline{p}-t_{s}-t_{e}\right) K$ in the second of the three lines above yields 


$$
\begin{gathered}
\hat{S}=\frac{a t_{S} d(S) / S}{K\left(p-\underline{p}-t_{S}-t_{e}\right)} D\left(1-\frac{t_{e} t_{S}}{p\left(p-\underline{p}-t_{S}-t_{e}\right)+t_{e} t_{S}}\right) \\
+\frac{a t_{S} S^{-1} L\left(p-\underline{p}-t_{S}\right)}{p\left(p-\underline{p}-t_{S}-t_{e}\right)+t_{e} t_{S}}-\delta_{S}
\end{gathered}
$$

Multiplying the numerator and the denominator of the first fraction by $p$, recognizing that $\left(1-t_{s} t_{e} /\left[p\left(p-p-t_{s}-t_{e}\right)+t_{s}\right.\right.$ $\left.+t_{e}\right]=p\left(p-p-t_{s}-t_{e}\right) /\left[p\left(p-p-t_{s}-t_{e}\right)+t_{s}+t_{e}\right]$ and cancellation of the denominator of this term with that of the first fraction yields $\left(3^{i v}\right)$ in the text. 